\title{
ON THE SPORES OF CERTAIN CONIFERAE.
}

W. C. COKER.

(WITH TWENTY-FOUR FIGURES)

The Pollen Grain.- There is much greater diversity in the male gametophyte of gymnosperms than of angiosperms. Such forms as Thuja, Taxodium, and Taxus have this structure so much reduced as closely to resemble, in the number of cells formed, the pollen grains of the flowering plants. Others, as Ginkgo, Pinus, and Podocarpus, contain, sooner or later, as many as six nuclei in the pollen grain and tube. In my paper on Taxodium I have summarized the present knowledge on this point in gymnosperms, and it is seen that much yet remains to be done before the structure of the pollen tube is understood in all genera.

During the spring of I902, while in Bonn, I examined almost daily the maturing pollen grains of a number of conifers, and followed them to the time of shedding. This was for the purpose of settling the point as to whether it were possible that a sterile prothallial cell or cells might be cut off early in development and, becoming disorganized, be overlooked in the ripe grain.

In the following species it was found that no division whatever occurred in the pollen grains while they were in the sporangium, and that they were shed in the one-celled stage: Cupressus Goveniana, C. macrocarpa, C. Benthamiana, Taxus baccata and vars. epacrioides, fastigiata, cuspidata, and adpressa, Juniperus sphaerica, J. chinensis.

In Cupressus sempervirens, pollen from a tree growing in the warm-house showed a division while still in the sporangium; but this variation from the rule in this genus probably resulted from delay in the dehiscence of the sporangium, caused by the unnatural conditions. It could easily be seen that dehiscence did not occur promptly and in some cases was only partial. Pollen grains of C. Benthamiana placed in sugar solution divided in a few cases in about a week.

In the following species there was one division of the pollen just 206

[September 
before shedding: Chamaecyparis Lawsoniana pendula, C. sphaeroidea, C. chinensis, C. obtusa, C. pisifera, Callitris sp., Cryptomeria japonica and var., Thuja orientalis.

The fate of these pollen cells was not followed further, but the appearance of the small cell cut off before shedding is quite unlike that of a prothallial cell, and bears every resemblance to the single (generative) cell cut off at the same time in Taxodium, where certainly no prothallial cell is formed. Furthermore, in all cases where prothallial cells are known to occur, they are produced while still in the sporangium, and the divisions that cut them off are immediately followed by another which gives rise to the generative cell. It is hardly to be doubted, therefore, that no prothallial cell is formed at any time in the species above mentioned.

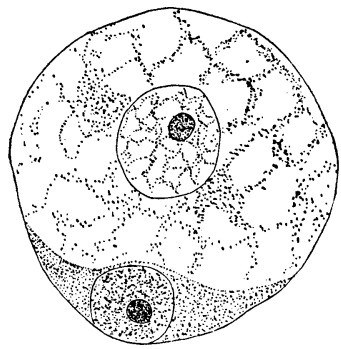

FIG. I. Thuja orientalis; pollen grain ready to shed. $\times$ I 700 .

In fig. $I$ is shown the mature pollen grain of Thuja orientalis, the exine not being drawn. The generative cell is of the usual structure and is sharply separated from the rest of the contents. Its nucleus is as usual more dense than the tube nucleus. In fig. 2 the pollen grain of Cupressus sempervirens is represented in division, while in fig. 3 the division is completed. In this last figure a few starch grains are shown. In most cases the generative cell is free from starch even
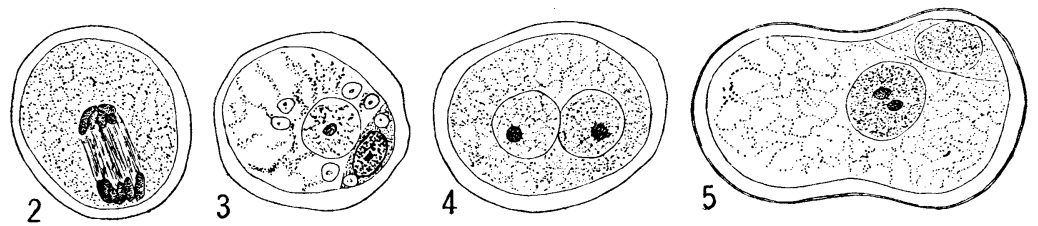

Figs. 2-5. Cupressus sempervirens; fig. 2, pollen grain in division; fig. 3, same ready for shedding; figs. 4 and 5 , abnormal pollen grains. $\times 75^{\circ}$.

in pollen where it is abundant, but here (fig. 3 ) it also contains a few scattered grains.

It will be seen that the above results confirm to a large extent STRASBURGER's observations on mature pollen. He finds ${ }^{\mathbf{x}}$ that in

I Ueber das Verhalten des Pollens, etc. I892. 
species of Taxus, Cupressus, and Juniperus the pollen grain divides only after reaching the nucellus; while in Thuja, Cephalotaxus, Podocarpus, Chamaecyparis Lawsoniana, Cryptomeria, Sequoia, Araucaria, and the Abietineae it divides before shedding.

In examining so many pollen cells it was not surprising that a good many abnormal forms were met with. In Cupressus it happened
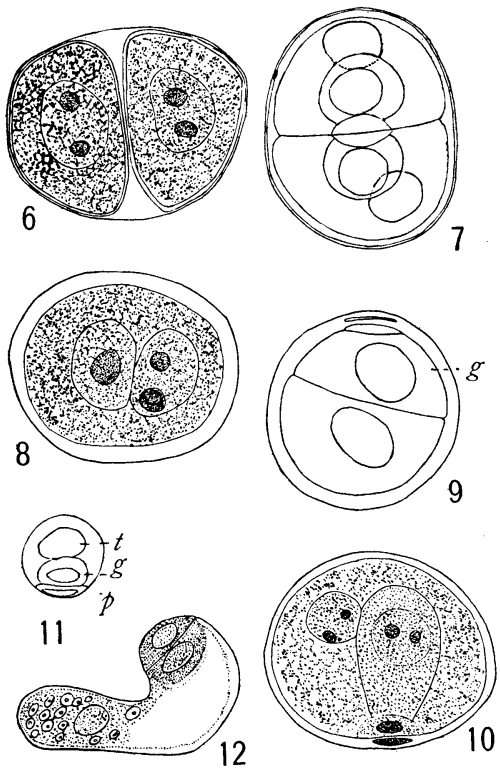

FIGS. 6-1o. Larix europaea; figs. $6-9$, abnormal pollen grains; fig. Io, normal grain. $\times 3$ I5. FIGS. II, I2. Encephalartos sp.; fig. II $\dot{I}$, shed pollen grain; fig. 12 , sprouting grain. $\times 3 \mathrm{I} 5$. not infrequently that the generative nucleus was not cut off in a separate cell of its own, but remained free in the general cytoplasm, side by side with the pollen tube nucleus. In such cases ( $f g .4$ ) the two nuclei were so much alike as to be hardly distinguishable. In fig. 5 is illustrated a pollen grain of peculiar shape and about twice the normal size. The generative cell, however, is of the usual appearance. It will be remembered that the tree from which this pollen was taken was not growing in perfectly congenial surroundings, and this may account for the rather unusual number of abnormalities.

In Larix europaea a number of cases were found in which the mother-cells had divided but once, so that only two instead of four pollen grains were formed ( $f g .6$ ). In some of these double grains the divisions proceeded about as usual. Fig. 7 gives such a case, but here only one prothallial cell is evident. Abnormal grains with two large free nuclei were also found ( fig. 8). In fig. 9 a generative cell $(g)$ of very unusual appearance is shown. For the sake of comparison a drawing is given of the normal pollen grain of Larix (fig. Io).

In Encephalartos sp. ? the mature pollen grain contained one prothallial cell, $p$, a generative cell, $g$, and a tube cell, $t$ (fig. II). No 
starch was found at this stage, but when the pollen was put in sugar solution it made its appearance in about two days. A sprouting grain that had been in sugar solution six days is shown in fig. I2. Here the prothallial cell and the generative cell are changed in position and the tube nucleus has moved down, and is surrounded by starch. One prothallial cell has been found in Ceratozamia, Zamia, and Cycas. ${ }^{2}$

The megaspore AND Embryo sac.-In the Cupressineae there is practically nothing known of the behavior of the megaspore mother-
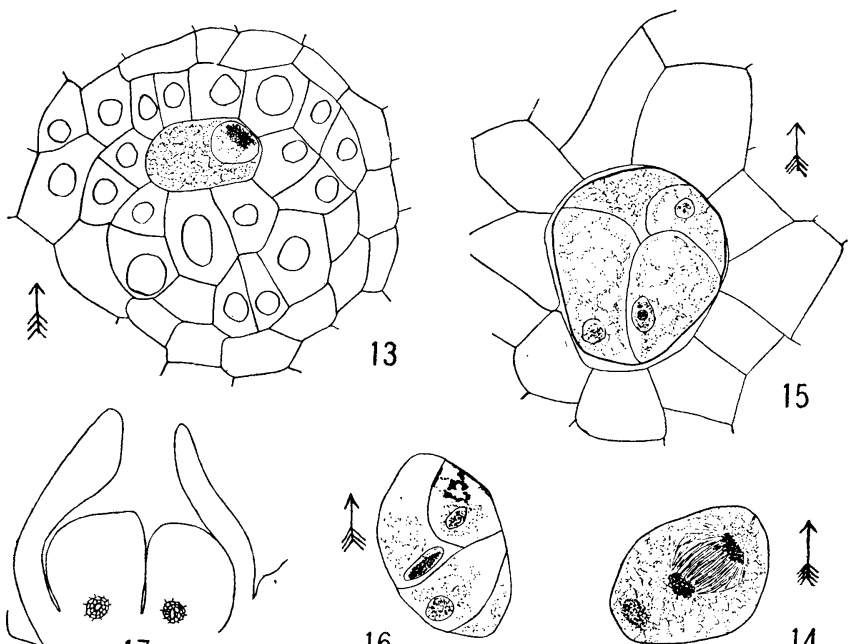

17

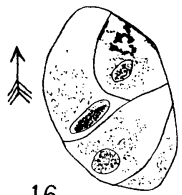

16

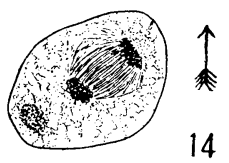

FIGs. I3-I7. Thuja orientalis; fig. I3, megaspore mother-cell surrounded by spongy tissue, $\times 335$; fig. I4, megaspore mother-cell during first division, $\times 525$; fig. ${ }_{15}$, tetrad of megaspores, $\times 525$; fig. 16 , the same, $\times 525 ;$ fig. I4, abnormal ovule with two sporongia, $\times 43$.

cell or of the origin of the megaspore. In Taxodium, which I consider as belonging to this group, the megaspore mother-cell divides into three potential spores, the largest of which is functional. As to other members of the group there is scarcely any literature that treats of this stage. Strasburger ${ }^{3}$ remarks that in Thuja the origin of the embryo sac is essentially as in Taxus.

2 The literature on this point is cited in my paper on Taxodium.

3 Die Angiospermen und die Gymnospermen. 1879 . 
Thuja.-In the hope of settling these points in some member of the Cupressineae, young ovules of Thuja orientalis were collected and sectioned in Bonn. The megaspore mother-cell soon becomes evident among the conspicuous spongy tissue. It has thicker walls and is also less dense than the cells around it. Its position is not always in the center of the spongy tissue, and its long diameter is as often as otherwise at right angles to the longitudinal axis of the ovule (fig. I3; the arrow shows the direction of the axis of the ovule). Occasionally there are two or three mother-cells developed, and in such cases they are generally separated by cells of the spongy tissue. In fig. I 3 the mother-cell nucleus is in synapsis, and in fig. I4 the first division spindle is shown. There is the same kinoplasmic mass at the lower end of the cell as in Larix sibirica ${ }^{4}$ and Taxodium. The spindle of the next division was not seen, but the result is shown in figs. I5 and 16 . Four megaspores are produced and their arrangement is more nearly that of the typical tetrad than in any other gymnosperm in which this stage has been described. After the completion of the last division, the spores may be seen packed together within the still nearly round mother-cell. They are never in a straight row, but are so arranged that in thin sections no more than three nuclei appear at once. The mother-cell wall around them also stains more deeply than those of the neighboring cells, so that the appearance approaches very closely what is found in the divided mother-cell of ferns. None of the spores is conspicuously larger than the others, and it was not determined which one became functional.

A peculiar abnormality in the ovule of Thuja orientalis is given in fig. I7. Two separate nucelli are present within the same sporangium and each has the usual sporogenous area. In other cases two fused sporangia were found in the same ovule, the sporogenous areas still being distinct. I have a preparation showing the same peculiarity in the ovule of Erythronium americanum; the nucellus is two-lobed and contains an embryo sac in each lobe.

Taxus.-Strasburger finds ${ }^{5}$ several megaspore mother-cells developed, and says that one or more of them divide into three or rarely

4 Juel, H. O., Beiträge zur Kenntniss der Tetradentheilung. Jahrb. Wiss. Bot. 35:626-659. pls. I5-16. I900.

5 Die Angiospermen und die Gymnospermen. 1879 . 

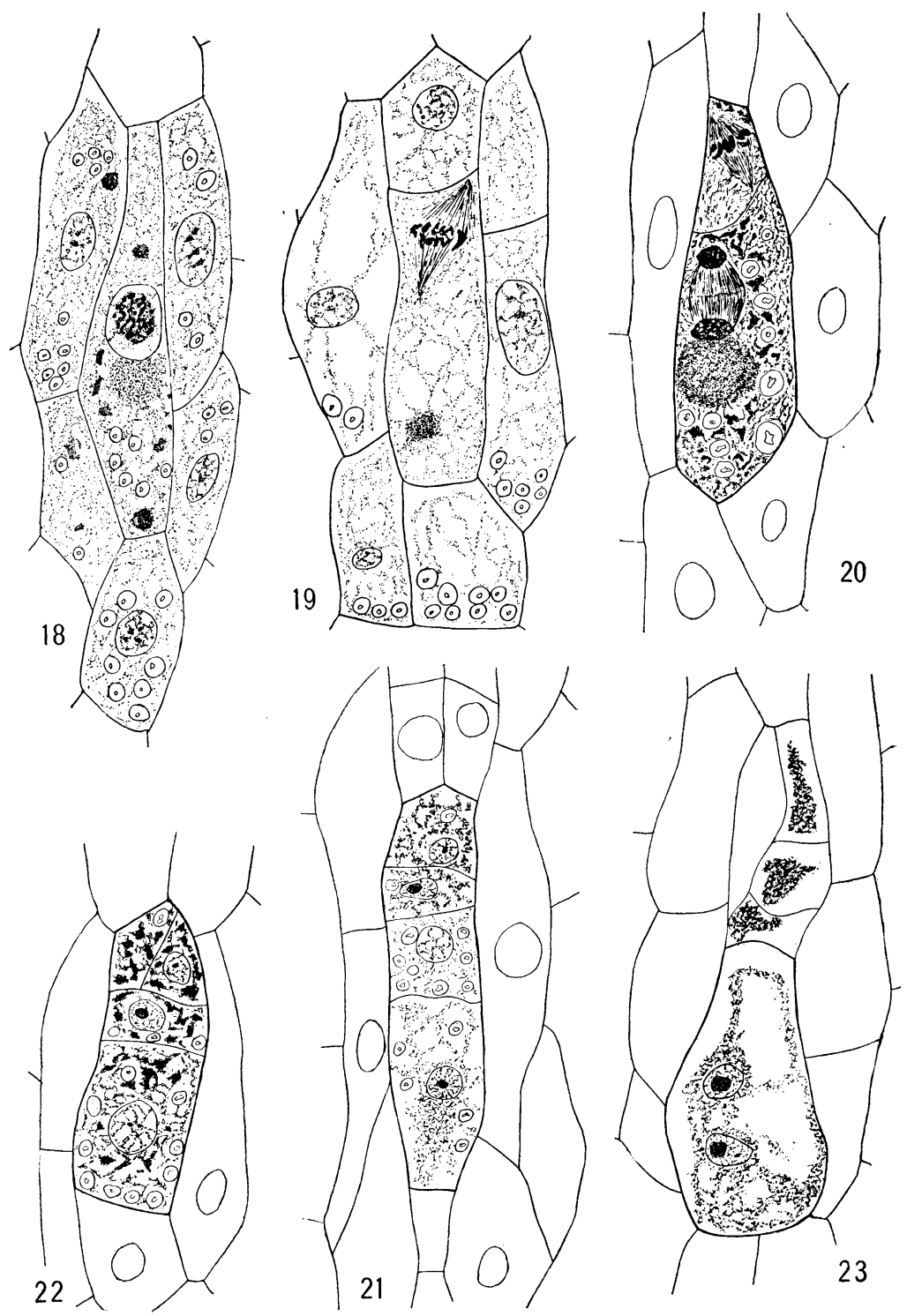

FIgs. I8-23. Taxus baccata; fig. I8, megaspore just before division, nucleus in synapsis, $\times 675$; fig. 19 , same during first division, $\times 675 ;$ fig. 20 , spindles of second division, $\times 675$; fig. 21 , four potential megaspores in a row, $\times 525$; fig. 22, four potential megaspores, the upper lying side by side, $\times 525 ;$ fig. 23 , sprouting of lower megaspore, $\times 625$. 
more cells lying in a row. JäGER ${ }^{6}$ with some hesitation agrees with STRASBURGER that there are three or four megaspores formed from the mother-cell; but it is pretty evident from his figures that he had before him not the spores, but the mother-cells and sterile tissue. JäGER also seems_to agree with StRASBURGER that there may be sev-

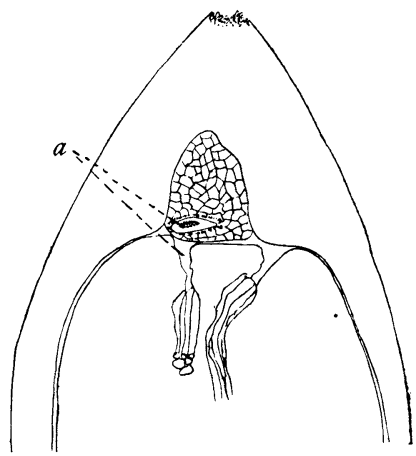

FIG. 24. Taxus canadensis; two prothallia in same ovule; embryos in lower, disorganizing archegonium in upper. $\times 43$. eral megaspore mother-cells. I cannot confirm these two observers as to the number either of the megaspore mother-cells or of the potential megaspores into which they divide. In my preparations there is no evidence that there is ever more than one megaspore mother-cell formed. The mother-cell is here harder to distinguish than in any other plant I have seen. At the time its first division occurs, it is long and narrow, resembling closely in shape the cells adjoining (figs. I8 and I9). It differs from them, however, in the possession of a rather conspicuous kinoplasmic mass near its lower end, resembling in this respect the mother-cells in Larix, Taxodium, and Thuja. Very rarely there is another smaller kinoplasmic mass above the nucleus. In fig. I8 the mother-cell is shown in the center with its nucleus in synapsis. The first division is given in fig. Ig. The spindle as here shown is at the upper end of the cell, and the division results in cutting off a small upper and a large lower part. The second division occurs simultaneously in both of these daughter-cells, as is shown in fig. 20 . This results in the formation of four potential megaspores, which lie as a rule in a single row ( $f i g .2 I$ ). The second division in the upper daughter-cell of the first division, however, may in some cases be at right angles to the longitudinal axis of the ovule, so that the two upper megaspores lie side by side (fig. 22). The long, narrow cells adjoining the megaspore mother-cell, which as mentioned above are well filled with starch, have remained undivided during these divisions. In some cases they divide into two, but they never resemble

${ }^{6}$ Beiträge zur Kenntniss der Endospermbildung und zur Embryologie von Taxus baccata. Flora 86:24I-288. pls. I5-I9. I899. 
the megaspore mother-cells, nor do their divisions give rise to cells resembling the megaspores. There seems no doubt that StrasBURGER and J ̈̈GER were wrong in giving the number of megaspores as generally three.

In addition to Taxus baccata and Thuja orientalis (as here shown) there are but three other conifers in which four potential megaspores have been definitely described. They are Larix sibirica, Pinus Laricio, and Sequoia sempervirens. ${ }^{7}$

As mentioned above, there is no spongy tissue surrounding the megaspore mother-cell in Taxus, and as the lower megaspore develops in sprouting, it crushes aside and destroys the cells immediately adjoining it, eating its way gradually into the more distant layers (fig. 23).

HoFMEISTER observed many years ago that more than one embryosac may occur in Taxus, and this I have found to be not uncommon in Taxus canadensis. Here one of the two prothallia, when two are present, is usually much smaller than the other. It is interesting to find that both prothallia may bear archegonia (fig. 24, a). The archegonia in the upper prothallium face towards the lower prothallium and not toward the micropyle, showing that the upper prothallium is inverted. The pollen tube does not stop at the upper end of the nearest prothallium, but growing past it presses in between the two to reach the archegonia. In all such cases it was the archegonia of the lower prothallium only that were fertilized (fig. 24).

In conclusion I wish to thank Professor Strasburger for his valuable advice and unfailing kindness. ${ }^{8}$

7 See my paper on Taxodium for literature.

8 The drawings have been inked in by Mr. H. A. Allard under my direction. 